\title{
The relation between complaints of persistent pain and family size
}

\author{
THOMAS A. GONDA ${ }^{2}$ \\ From the Institute of Experimental Psychology, University of Oxford, and the Department \\ of Neurology, United Oxford Hospitals
}

Physicians with a profound interest in the problems of pain have long concluded, on the basis of clinical experience, that early interpersonal relationships have an important role in determining a patient's subsequent behaviour when he experiences pain (Engel, 1959; Russell, 1959). However, there are very few systematic studies in the medical literature that relate significant dimensions of interpersonal relationships, for example, the family constellation, to complaints of pain. Button (1953) enquired into the effects of adrenocorticotrophic hormone upon patients with 'intractable pain'. His sample of 27 complainers of chronic pain was compared later with a representative sample of neurological patients on a number of dimensions. These included sex, age, family size, marital status, religion, social class, education, economic status, intelligence, and various personality factors. The results of this comparison showed, in essence, that patients comprising the 'intractable pain' group came from significantly larger families than the 'representative controls'. In no other variables measured were there significant differences. There was, however, a trend toward a greater elevation of the $\mathrm{Pa}$ and $\mathrm{Pd}$ scales on the Minnesota multiphasic personality inventory in the group of subjects complaining of persistent pain; this sample also generally gave the impression during psychiatric interviews of greater emotional maladaptation. That these observations were not differentially reflected in the psychiatric diagnoses given to the members of the two groups is not surprising in view of the high incidence of primary and secondary psychiatric diagnoses $(60 \%)$ found in a representative hospital neurological population (Fisher and Gonda, 1955).

The current paper is concerned with a further investigation of the relationship between the com-

${ }^{2}$ This investigation was carried out during the tenure of a special fellowship from the National Institute of Mental Health, United States Public Health Service.

'On leave from the Department of Psychiatry, Stanford University, California. plaint of pain and the size of the family of the complainer.

\section{MATERIAL AND METHODS}

SELECTION OF SAMPLES One hundred and twenty-three of 129 consecutive patients, 13 years of age and over, were given a structured interview during the course of their visit to the Radcliffe Infirmary neurological out-patient clinic.

Of the patients comprising the sample, some were told by their neurologist that the investigator was interested in talking to them briefly but more generally the patients were only told by the nurse to wait for a further examination. Most of the patients appeared interested and were cooperative, with but a handful showing overt annoyance at the extra procedure and only one refusing to be interviewed. Of the six patients who were missed four came early in the series before an effective routine for temporarily detaining them had been fully worked out.

The minimal information obtained from each of the patients included presenting medical complaints with details, sex, date of birth, place of birth, where brought up, number of siblings and their ages, number and ages of other persons living in the home during childhood, religion, education, marital status, as well as own and/or spouse's occupation, and father's occupation. Care was taken as far as possible to obtain the data in the sequence listed above. In all cases the investigator obtained the details of the chief medical complaint before he put any questions about the number of siblings.

Looking at very broad medical diagnostic categories the total sample appeared to represent an adequate cross-section of neurological disease.

PRIMARY GROUPING OF SAMPLES The 123 patients comprising the total sample were classified into two groups according to whether the symptom of pain was present or absent from the chief complaint. This resulted in one group of 49 patients in whom pain was a part of the chief complaint $(+)$ and another group of 74 patients in whom pain was absent from the chief complaint $(-)$. A check on the reliability of this classification based on findings at interview by comparing it with $\mathrm{a}(+)$ and $(-)$ 
pain complaint grouping derived solely from material in the medical records revealed seven instances in which the ratings differed. In five of these pain was a presenting complaint to the investigator, but it was not so recorded in the medical charts, while in the remaining two instances the reverse occurred (Phi coefficient $=0 \cdot 88$ ).

For purposes of further analysis the $(+)$ group complaining of pain was subdivided in accordance with the duration of the complaint of pain. These subgroups consisted of patients who had complained of pain to physicians for less than six months (15), for six to 17 months (5), for 18 to 59 months (11), and over 60 months (18). When the duration of the complaint of pain obtained from the interview data was compared with that found in the medical record a high agreement was present in patients with either recent (less than six months) or with very persistent (over 60 months) complaints of pain.

The findings at interview of the presence or absence of complaints of pain as well as of its duration were used in the following comparisons.

\section{FINDINGS}

The results of comparing the complainer group $(+)$ with the group which did not have pain as a complaint (-) are summarized in Table I. It is at once apparent that the groups correspond very closely on the following parameters: Where brought up, religion, marital status, and social class of the parents. (The last was determined according to occupational criteria as listed by the General Register Office, 1960.) The differences between groups in age, sex distribution, and family size bear further scrutiny.

AGE There was a gradual and fairly even spread of birth dates from 1948 to 1891 , with one patient born in 1884. Therefore, in view of the well known clinical observation that diseases which are associated with complaints of chronic pain tend to occur more frequently later in life, the statistically significant finding in Table $I$ regarding the age differences between ( + ) and ( $(-)$ groups is quite expected. Accordingly, to take this tendency into account in further analysis of the data, the total sample was divided into three age groups each containing approximately equal numbers of patients. As a result of this division there emerged three groups (Table II) in which there were no significant differences between the ages of those complaining of pain and those not complaining of pain. The tendency for an increasing incidence of complaints of pain with increasing age is further demonstrated by this division (Table III).

SEX Distribution The trend toward a greater proportion of women than men to complain of pain to physicians appears to be associated with the women
TABLE I

COMPARISON OF GROUPS WITH AND WITHOUT COMPLAINT OF PAIN

\begin{tabular}{llll} 
+Pain & Pain & $\begin{array}{l}\% \text { of } \\
\text { Total }\end{array}$ & Probability \\
\hline
\end{tabular}

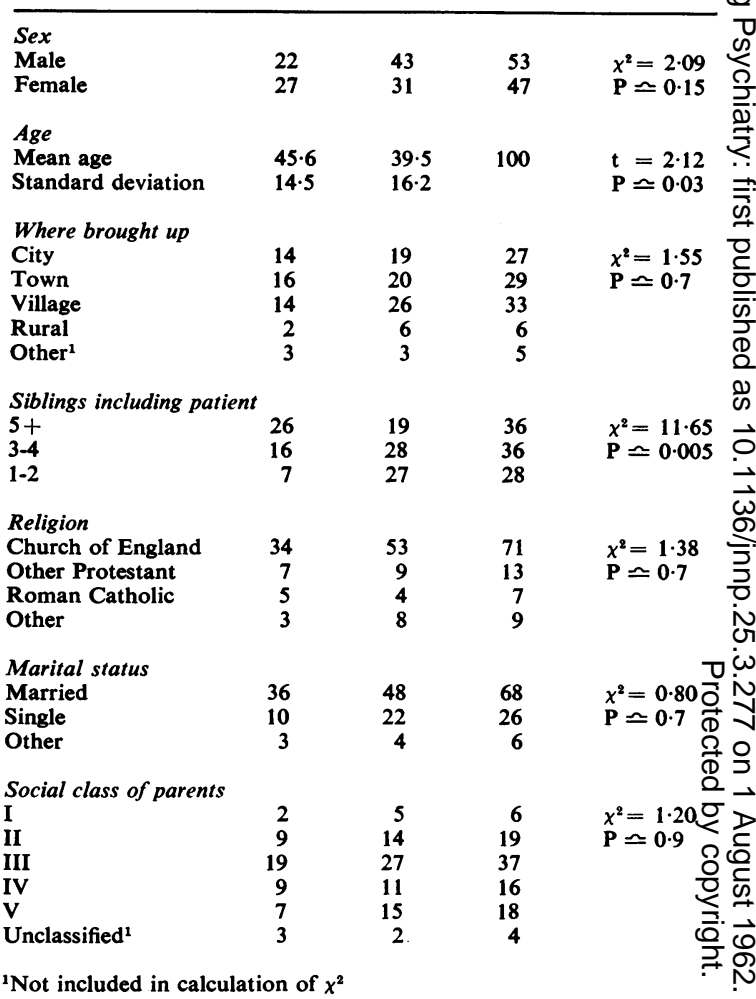

TABLE II

COMPARISON OF MEAN AGES OF THREE AGE GROUPS WITH AND WITHOUT COMPLAINT OF PAIN

\begin{tabular}{llllll} 
Groups & Ages & +Pain & - Pain & Probability \\
\hline I & $51+$ & $58.3 \pm 6.0$ & $59.8 \pm 6.7$ & $t=0.75$ & $P \bumpeq 0.5$ \\
II & $36-50$ & $43.4 \pm 4.4$ & $42.5 \pm 3.8$ & $t=0.61$ & $P=0.5$ \\
III & $13-35$ & $26.4 \pm 7.7$ & $23.0 \pm 6.0$ & $t=1.37$ & $P \bumpeq 0.2$
\end{tabular}

TABLE III

COMPARISON OF INCIDENCE OF COMPLAINT OF PAIN IN VARIOUS AGE GROUPS

\begin{tabular}{llcccc} 
Groups & Ages & + Pain & - Pain & $\%+$ & Probability \\
\hline I & $51+$ & 22 & 21 & 51 & $\chi^{2}=4 \cdot 01$ \\
II & $36-50$ & 14 & 23 & 38 & P $\bumpeq 0.07^{1}$ \\
III & $13-35$ & 13 & 30 & 30 & \\
Total & $13-77$ & 49 & 74 & 40 &
\end{tabular}

'One-tailed test. 
TABLE IV

COMPARISON OF SEX DISTRIBUTION OF COMPLAINERS OF PAIN IN VARIOUS AGE GROUPS

\begin{tabular}{|c|c|c|c|}
\hline & +Pain & -Pain & Probability \\
\hline $\begin{array}{l}\text { Group I }(51+\text { years }) \\
\text { Male } \\
\text { Female }\end{array}$ & $\begin{array}{l}10 \\
12\end{array}$ & $\begin{array}{l}11 \\
10\end{array}$ & $\begin{array}{l}x^{2}=0.18 \\
P \bumpeq 0.67\end{array}$ \\
\hline $\begin{array}{l}\text { Group II (36-50 years) } \\
\text { Male } \\
\text { Female }\end{array}$ & $\begin{array}{l}8 \\
6\end{array}$ & $\begin{array}{l}13 \\
10\end{array}$ & $\begin{array}{l}x^{2}=0.005 \\
P \simeq 0.95\end{array}$ \\
\hline $\begin{array}{l}\text { Group III (13-35 years) } \\
\text { Male } \\
\text { Female }\end{array}$ & $\begin{array}{l}4 \\
9\end{array}$ & $\begin{array}{l}19 \\
11\end{array}$ & $\begin{array}{l}x^{2}=4.39 \\
P \bumpeq 0.04\end{array}$ \\
\hline
\end{tabular}

35 years of age and under (Table IV). This trend well may be, in part, a reflection of the nearly 2 female: 1 male ratio associated with migraine (Selby and Lance, 1960) and with 'psychogenic regional pain' (Walters, 1961).

FAMILY SIZE In this study family size is defined specifically as the total number of the patient's siblings (all live births) plus the patient. Using this criterion for family size, it is quite apparent from Table I that a very significant correlation exists between family size and the complaint of pain.

The various factors which ordinarily have been associated with family size include: 1 , Age; 2 , urbanrural dimension; 3, social class of parents; and 4, religion. As shown in Table $\mathrm{V}$, in this sample the last three do not correlate significantly with family size whereas age does. The correlation between where the patient was brought up and his family size seems only to highlight a trend for town, village, and farm families to be larger than their city counterparts. Moreover, since the correlations between all

TABLE V

COMPARISON OF GROUPS FROM SMALL AND FROM LARGE FAMILIES

$\frac{\text { Siblings }}{1-3 \quad 4+} \%$ of Total Probability

Age (years)

51+

13-35

$\begin{array}{lll}13 & 30 & 35 \\ 16 & 21 & 30 \\ 30 & 13 & 35\end{array}$

$\chi^{2}=14.00$

Where brought up

City

Town, village or farm

20

48

13

28

Social class of Father

I-II

IV-V

18

Religion

Church of England

Other Protestant

Roman Catholic

Other three of these factors (social class of parents, religion, and where brought up) and the complainer: noncomplainer of pain dimension are not significant in this sample, no additional analysis of these dimensions appears warranted. Table VI even further illuminates, both in the sample studied and in the British population as a whole (Royal Commission on Population, 1950; General Register Office, 1952), the very significant relationship between age and family size shown in Table $\mathrm{V}$.

TABLE VI

COMPARISON OF FAMILY SIZES IN VARIOUS AGE GROUPS

\begin{tabular}{|c|c|c|c|c|c|}
\hline \multirow[t]{2}{*}{ Group } & \multirow[t]{2}{*}{ Ages } & \multicolumn{2}{|c|}{ Median Size } & \multicolumn{2}{|l|}{ Mean Size } \\
\hline & & This Study & Britain & This Study & Britain \\
\hline $\begin{array}{l}\text { I } \\
\text { II } \\
\text { III } \\
\text { Total }\end{array}$ & $\begin{array}{l}51+ \\
36-50 \\
13-35 \\
13-77\end{array}$ & $\begin{array}{l}\mathbf{4} \cdot 72 \\
3 \cdot 30 \\
2 \cdot 29 \\
3 \cdot 13\end{array}$ & $\begin{array}{l}4 \cdot 71 \\
3 \cdot 42 \\
2 \cdot 46 \\
3 \cdot 23\end{array}$ & $\begin{array}{l}5 \cdot 49 \\
4 \cdot 30 \\
3 \cdot 14 \\
4 \cdot 22\end{array}$ & $\begin{array}{l}3.52 \\
2.62 \\
2.05 \\
2.53\end{array}$ \\
\hline
\end{tabular}

Data thus far presented in this paper about family size show: 1 That larger family size and increased age are highly related to each other, and 2 , that both larger family size and increased age are highly related to the complaint of pain. By comparing populations which are matched for age (Table II) the relationship between complaint of pain and family size can be more accurately parcelled out. The results of this procedure are to be found in Table VII which shows that in this sample the increased complaint of pain is related to larger

\section{TABLE VII}

COMPARISON OF FAMILY SIZE AND COMPLAINT OF PAIN IN VARIOUS AGE GROUPS

\begin{tabular}{lrrr} 
& Pain & - Pain & Probability \\
\hline Group I (51 + years) & & & \\
1-5 siblings & 8 & 15 & $\chi^{2}=5.34$ \\
$6+$ & 14 & 6 & $P=0.02$ \\
Group II (36-50 years) & & & \\
$\begin{array}{l}\text { 1-4 siblings } \\
\text { 5+ }\end{array}$ & 6 & 18 & $\chi^{2}=4.82$ \\
Group III (13-35 years) & 8 & 5 & $\mathrm{P} \bumpeq 0.03$ \\
$\begin{array}{l}\text { 1-3 siblings } \\
\text { 4+ }\end{array}$ & 7 & & \\
& 6 & 23 & $\chi^{2}=2.23$ \\
& & 7 & $P \bumpeq 0.14$
\end{tabular}

family size independently of age. This correlation is quite striking in groups I and II which include all patients born before 1926 but appears only as a trend in group III which is comprised of persons born during the 1926 to 1948 period.

On the basis of 1 , the rationale that there are clinical differences between the shorter-term and the more chronic complainers of pain and 2, the earlier findings concerning 'intractable pain' and large 
family size, the grcup $(+)$ complaining of pain was subdivided in the manner cited above in accordance with the duration of the complaint of pain. Some of the results of comparing duration of complaint with family size are summarized in Table VIII which shows that family sizes of long-term complainers of

\section{TABLE VIII}

COMPARISON OF DURATION OF COMPLAINT OF PAIN AND FAMILY SIZE

\begin{tabular}{lccc} 
Complaint of Pain & $\begin{array}{l}1-4 \\
\text { Siblings }\end{array}$ & $\begin{array}{l}5+ \\
\text { Siblings }\end{array}$ & Probability \\
\hline (-) No pain & 55 & 19 & $\chi^{2}=1 \cdot 29$ \\
(+) Under 6 months & 9 & 6 & $\mathrm{P} \bumpeq 0 \cdot 25$ \\
(-) No pain & 55 & 19 & $\chi^{2}=11.01$ \\
(+) Over 6 months & 14 & 20 & $\mathrm{P} \bumpeq 0.001$ \\
(-) No pain plus (+) under & & & \\
6 months & 64 & 25 & $\chi^{2}=10 \cdot 12$ \\
(+) Over 6 months & 14 & 20 & $\mathrm{P} \bumpeq 0.001$ \\
(+) Under 6 months & 9 & 6 & $\chi^{2}=1.47$ \\
(+) Over 6 months & 14 & 20 & $\mathrm{P} \bumpeq 0.23$ \\
(+) Under 6 months & 9 & 6 & $\chi^{2}=2.31$ \\
(+) Over 60 months & 6 & 12 & $\mathrm{P} \bumpeq 0.13$
\end{tabular}

pain are significantly larger than those of persons without ccmplaints of pain. In addition, persistent complainers of pain tend to come from larger families than do short-term complainers of pain. That this distinction is not greater is probably because the short-term group contains patients who will eventually become members of the chronic group. On the other hand, the short-term complainers of pain come from families which do not differ significantly in size from those of the patients without complaints of pain.

\section{DISCUSSION}

COMMENTS ON THE DATA In considering the reliability of the data, some estimates, at least, are possible in each of the major parameters. Information about sex and date of birth is probably of consummate reliability. It appeared to the investigator that questions concerning religious preference would be answered very similarly if asked again. Social class based upon occupation presents many problems, both in terms of technical difficulties in its determination and in terms of its meaningfullness. Suffice it to say that we can hope that the errors were of equal quality, dimension, and direction in both the complainers of pain and those not so complaining. Regarding education, particularly of persons over 40 years of age, the high incidence of a marked, but directionally and quantitatively inconsistent, discrepancy between the stated number of years of school attendance and the ages of starting and stopping school precluded the use of this dimension in the statistical analysis. The reliability of the rating of the presence or absence of complaints of pain and of the time during which pain was complained of to doctors has been dealt with earlier. It may be added here that in the 18 instances in which complaints of pain in a fairly regular pattern were chronically present there was invariably a letter from the patient's personal physician commenting on this. Typically, such comments included statements of the regularity of patient's visits and persistence of his suffering despite all measures tried. On the 'no pain' complaint side there were only rarely notes which specified that to be the case. An example is the statement: 'Despite her advancing deformities which more and more limit her activities and must be extremely painful to her, she has not once complained of the pain'. As to the number of brothers and sisters, the figure used was that finally obtained after questioning about the names, years of birth, sex, and state of health of the siblings, and it appears to be highly reliable.

In addition to comments about reliability, further remarks are also in order about the findings on the relationship between family size and the complaint of pain. Despite continuing scepticism on the part of the investigator about the generality of this finding, there is no question of its existence in this and a previous sample. That this relationship is clearly in evidence in persons over 35 years of age, but only represents a trend in the younger age group, seems to be on the basis of a marked reduction in family size which had taken place (Tables V and VI), and a comparatively low incidence of complaints of pain in the younger patients (Table III).

REMARKS ON THEORY There are any number of theoretical frameworks in which the current data can be adequately accounted for. Such speculative exercises may well await the further accumulation of information about pain and family constellations. Notwithstanding, one hypothesis that appears to be worthy of mention at present is that suggested by Sarbin (1962), and I propose for consideration the following modification of Sarbin's thesis. Central to that thesis is the well-grounded assumption that the infant's experience of pain (Gonda, 1962) represents a stress which motivates him to attempts by trial and error to reduce the tension and through the mechanism of 'complaint' he often finds that he obtains assistance. In large families more opportunities exist (parental plus sibling) for such seeking to be effective in reducing stress. Then, in later life, when painful experiences arise again the means learned as a child of reducing tension expresses itself in the tendency to seek assistance by complaining of pain and in adopting the role of an invalid. Members of larger families, particularly the younger children, 
would tend to have found this type of activity effective earlier and would probably be more likely to revert to it. The doctor is, in such a situation, not only a 'parent substitute' but also one of the 'sibling surrogates'. Other findings in this investigation, such as those concerning the relationship of the complaint of pain and a variety of family dimensions, including ordinal position, tend to support this hypothesis and will be reported later.

\section{SUMMARY}

A study of a representative neurological out-patient population of 123 in a number of dimensions reveals a relationship between family size and complaint of pain. Specifically, those patients who persistently complain of pain tend to have significantly more siblings than those who do not complain of pain to their doctors.
I wish to thank Dr. W. Ritchie Russell for permission to interview and to use records of patients who were under his care, and also Dr. Charles W. M. Whitty for his many courtesies and kind cooperation.

\section{REFERENCES}

Button, A. D. (1953). Dissertation Abstracts, 13, 873.

Engel, G. L. (1959). Amer. J. Med., 26, 899.

Fisher, J., and Gonda, T. A. (1955). A.M.A. Arch. Neurol. Psychiat., $74,117$.

General Register Office (1952). Census 1951 Great Britain, One Per Cent Sample Tables, Part II. Her Majesty's Stationery Office, London.

(1960). Classification of Occupations. Her Majesty's Stationery Office, London.

Gonda, T. A. (1962). Bull. Brit. psychol. Soc., 47, 29.

Royal Commission on Population (1950). Papers Vol. 2: Reports and Selected Papers of the Statistics Committee. Her Majesty's Stationery Office, London.

Russell, W. Ritchie (1959). Proc. roy. Soc. Med., 52, 983.

Sarbin, T. R. (1962). Personal communication.

Selby, G., and Lance, J. W. (1960). J. Neurol. Neurosurg. Psychiat., 23, 23.

Walters, A. (1961). Brain, 84, 1.

\section{The May 1962 Issue}

\section{THE MAY 1962 ISSUE CONTAINS THE FOLLOWING PAPERS:-}

Observations on blink reflexes GEOFFREY RUSHWORTH

Regulatory mechanisms in Parkinsonian tremor WILLIAM WARD HOFMANN

The effects of adrenaline, noradrenaline, and isoprenaline on Parkinsonian tremor c. CONSTAS

Observations on essential tremor JOHN MARSHALL

The psycho-galvanic reflex M. H. LADER and J. D. MONTAGU

Clinical study of the numerical variation with age of compact nerve endings in the human conjunctiva $\mathrm{P}$. M. RIISAGER

Studies in spina bifida cystica Part II: When to repair the spinal defect A. N. GUTHKELCH

A chemical investigation of the defects of myelination in phenylketonuria L. CROME, V. TYMMS, and L. I. WOOLF
The association of phenylketonuria with leucodystrophy L. CROME

The problem of prosopagnosia E. S. BEYN and G. R. KNYAZEVA

Teratomatous cysts within the vertebral canal DICK HOEFNAGEL, KURT BENIRSCHKE, and JOSE DUARTE

Nerve root compression associated with narrowing of the lumbar spinal canal JOSEPH A. EPSTEIN, BERNARD $\mathbf{S}$. EPSTEIN, and LEROY LAVINE

An immunochemical study of the proteins in cerebrospinal fluid F. D. ROSENTHAL and J. F. SOOTHILL

Proceedings of the Society of British Neurological Surgeons: 64th meeting

Book reviews

Copies are still available and may be obtained from the PUBLISHING MANAGER, BRITISH MEDICAL ASSOCIATION, TAVISTOCK SQUARE, W.C.I, price 17s. 6D. 